\title{
Riding Off into the Sunset
}

\author{
Leslie R. Dye
}

Published online: 23 September 2014

(C) American College of Medical Toxicology 2014

When asked if I wanted to write my swan song for $J M T$, I was reluctant. I want the transition from my position as Editor-inChief to Dr. Mycyk's to be seamless. But I thought this was a good opportunity to point out the accomplishments of the journal over the last several years.

After being the editor of a monthly heath magazine for the lay public in the Cincinnati Enquirer and serving as the managing editor for a new medical journal, Innovations, the official journal for the International Society for Minimally Invasive Cardiac Surgery (ISMICS), I applied for a position with $J M T$. I took the position as the associate editor of the Journal of Medical Toxicology (JMT). Christian Tomaszewski was the editor-in-chief; a college English professor, Sean Kullman, was our managing editor; and our publisher was Pennsylvania Press. It was a wonderful team - Chris was the researcher/scientist, I was the organizer, and Sean was an incredible copy editor, and more. There was no content management system, so all of the manuscript management was done by email. That was not an easy task! We did eventually get limited access to Editorial Manager, which made a huge difference. Our big accomplishment was our acceptance for indexing by Medline. When Sean left, I agreed to continue as associate editor but also became managing editor.

The next big transition was changing publishers, and we signed a contract with Springer. I became the editor-in-chief, but maintained my position as managing editor. Learning about a big publishing house was the next step in my publishing education. We have benefited tremendously from our relationship with Springer, increasing revenue and our exposure to more medical libraries. During my tenure as editor-in-chief, we accomplished a great deal. We expanded and focused on educating the editorial board. Over the years, six fellows in

L. R. Dye $(\square)$

Waynesville, OH, USA

e-mail: leslierdye@me.com training completed terms on the editorial board. We expanded our features and developed many policies for the journal, including a conflict of interest policy, appeals process, a policy for addressing plagiarism, guidelines for authorship, and a process for evaluating reviewers. We published papers describing the process for producing a good case report and one for a review paper. A process was developed for the editorial board to undergo an annual performance review, increasing accountability. JMT also entered the world of social media with both Twitter and Facebook accounts and the wonderful JMT podcast. Over the years, I have tried to educate myself by joining the Council of Science editors, joining several publishing ethics organizations, attending the Peer Review Congress in Chicago, and taking an intensive editors' course.

The best part of my JMT story is also the worst. Because of all that I learned working with $J M T$, it prepared me for my current job, forcing me to leave $J M T$ to join Elsevier.

But the journal is not about a single person; it is about a large group of very dedicated members of the American College of Medical Toxicology (ACMT), including the editorial board, the ACMT board of directors, the reviewers, authors, and those at Springer. I have to thank some very special people. The most important thank you goes to the editorial board. This group is so wonderful, energetic, and wise. They are the journal. Fortunately, I will continue to work with them in my role as ACMT president. I thank Mark Mycyk for being a guiding voice as my associate editor, and I know the journal will grow in his very capable hands. Lewis Nelson continues to serve as my confidante and grammar guru; his support and friendship are invaluable. Howard Greller and Dan Rusyniak joined me on many bike rides while I listened to the JMT podcast. They make my life brighter with their friendship and their humor. Michael Weston was my unwavering mentor as our publishing contact at Springer, becoming a good friend.

How can any ACMT thank you be complete without including Paul Wax and Tricia Steffey? I have known Paul 
since 1989. We have maintained our collegial relationship and friendship. Paul tirelessly advocates for every part of ACMT, including JMT. He is responsible for initiating the relationship with Springer and always encouraged the journal to be better. I am not sure words can express Tricia's role. In addition to all she does for ACMT, she also was my main administrative support person for JMT. She is one of the most incredible people and one of the hardest workers I have ever met.

I also have to thank my husband, Brian, for always supporting me and never complaining about extra hours spent working.
Now, for my Oscars thank you, how can a sincere thank you and swan song be complete without thanking my parents? My father was an engineer and my mother an English teacher- the perfect recipe for a medical editor. I was so blessed to get the best of both of them. They are/were truly amazing people.

Now, we are on to the next phase. I look forward to watching the journal, under Mark's direction, continue to excel. The future looks very bright.

Conflict of Interest None disclosed. 